\title{
Gaya Kepemimpinan Yang Ideal Untuk Generasi Milineal
}

\author{
Riki Andi Saputro \\ Universitas Sebelas Maret \\ rikiandisaputra33@gmail.com
}

\section{Article History}

received $1 / 9 / 2021$

\begin{abstract}
Leadership is an ability or strength in a person to lead and influence others in terms of work, where the goal is to achieve predetermined goals. The development of today's era has influenced all aspects, including aspects of leadership style. In today's millennial generation, the challenge of having an ideal leader that fits the current era is very big. This study aims to see how the ideal leadership style. The focus of the research is to examine the ideal leadership style for the millennial generation. The method used in this research is literature study related to theory and references. The results of the research on the ideal leadership style for the millennial generation, namely effective government will be realized if the leader can meet the qualifications as a credible leader, has the ability, intellect, good vision and has integrity, honesty and loyalty to interests. from the community. Building a region that is led must have a foundation, namely independence and entrepreneurship that gives pleasure and satisfaction to the community. Leadership in the millennial era has a unique approach because digitalization that has penetrated the world of work no longer allows leaders to act conventionally.
\end{abstract}

Keywords: Leadership Style, Ideal, Millennial Generation

\begin{abstract}
Abstrak
Kepemimpinan merupakan sebuah kemampuan atau kekuatan di dalam diri seseorang untuk memimpin dan mempengaruhi orang lain dalam hal bekerja, dimana tujuanya adalah untuk mencapai target (goal) yang telah ditentukan. Perkembangan zaman saat ini telah mempengaruhi segala aspek, tidak terkecuali aspek gaya kepemimpinan. Pada generasi milinial saat ini tantangan untuk memiliki pemimpin ideal yang sesuai dengan era saat ini sangatlah besar. Penelitian ini bertujuan untuk melihat bagaimana gaya kepemimpinan yang ideal. Fokus penelitian untuk mengkaji gaya kepempimpinan yang idelal untuk generasi milineal. Metode yang digunakan dalam penelitian ini studi pustaka yang berkaitan dengan teoritis dan referensi. Hasil penelitian gaya kepemimpinan yang ideal untuk generasi milineal yaitu pemerintahan yang efektif akan terwujud apabila para pemimpin dapat memenuhi kualifikasi sebagai pemimpin yang kredibel, mempunyai kemampuan, intelektual, visi yang baik dan memiliki integritas, kejujuran dan kesetiaan pada kepentingan dalam masyarakat. Membangun suatu daerah yang dipimpin harus memiliki fondasi yakni kemandirian dan entrepreneurship yang memberikan kesenangan dan kepuasan kepada masyarakatnya. Kepemimpinan pada era milineal memiliki pendekatan yang khas karena digitalisasi yang merambah dunia kerja tidak lagi memungkinkan pemimpin untuk bertindak secara konvensional.
\end{abstract}

Kata Kunci: Gaya Kepemimpinan, Ideal, Generasi Milineal

Social, Humanities, and Education Studies (SHEs): Conference Series https://jurnal.uns.ac.id/shes

p-ISSN 2620-9284

e-ISSN 2620-9292 


\section{PENDAHULUAN}

Sebagai bangsa yang besar dan semakin diperhitungkan di kancah internasional. Indonesia memiliki banyak tantangan yang harus diselesaikan. Membangun Indonesia berarti membangun mental rakyatnya sehingga gagasan revolusi mental rakyatnya sehingga gagasan revolusi mental lahir dan di cetuskan pemerintah sebagai gerakan yang masif (Novita, 2020: 4). Untuk proses perubahan besar itu, kepemimpinan model lama pun mulai ditinggalkan karena model lama tidak akan cocok lagi oleh karena itu harus di koreksi atau dikembangkan. Setiap zaman punya ceritanya sendiri, setiap generasi punya gaya hidupnya sendiri, masing-masing menjadi ciri khas yang alamiah (Irawan, 2019: 8).

Teknologi memiliki peran penting dalam mewarnai bahkan mengubah sudut pandang sebuah generasi, perubahan sudut pandang tersebut tidak bisa dihindari karena itu merupakan sebuah keniscayaan (Mustomi dkk, 2020: 73). Teknologi sedikit banyak akan mempengaruhi sudut pandang masyarakat terhadap sesuatu yang pada akhirnya menjadi bagian dari sebuah peradaban (Saputro dkk, 2020: 8). Teknologi menjadi unsur yang tidak terpisahkan bagi generasi milineal, rasa-rasanya tanpa teknologi misalnya handphone, hidup serasa belum ideal (Hambali, 2019: 110).

Dengan perkembangan di semua lini kehidupan terjadi semakin cepat. Kemajuan teknologi informasi menjadi bagian yang tak terpisahkan dari masyarakat saat ini (Rais dkk, 2019: 63). Laju informasi dan pengetahuan pun begerak begitu cepat tanpa kendala. Semua berubah dalam hitungan sekian menit (Mustomi dkk, 2020: 74). Mulai dari proses penggalian informasi maupun penyebaran berita, tren teknologi terjadi sangat cepat. Seakan mereka yang begerak lamban akan tergilas dan tertinggal jauh dibelakang (Saputro, 2021: 124).

Seperti halnya para generasi muda di Indonesia yang tumbuh begitu pesat, maka gaya kepemimpinan yang muncul pun harus menyesuaikan kepada ritme dan perkembanganya. Generasi milineal yang saat ini mempengaruhi banyak hal juga harus dipimpin dengan pemimpin dengan gaya kepemimpinan milineal (Suhadi dkk, 2020: 131). Menjadi seorang pempimpin yang baik dan jujur pada generasi masyarakat milineal saat ini dan kedepan menjadi satu tantangan yang kritis (Azzahra dkk, 2019: 5). Seiring perkembnagan zaman, beberapa pemimpin muncul akabit tuntutan dan kondisi lingkungan pada saat itu. Pada zaman penjajahan, karakter pemimpin terbentuk dalam perjuangan melawan penjajah (Moris, 2021: 92). Mereka pejuang yang terbentuk oleh intelektual dan memiliki idealisme yang bisa menghasilkan rumusan ideologi bangsa yang menjadi dasar-dasar dan pedoman perjalanan dan kehidupan bangsa kita (Hambali, 2019: 115).

Untuk mencari pemimpin yang baik maupun tepat untuk masa sekarang ini dan masa yang akan datang menjadi tantangan yang harus terpenuhi untuk bangsa ini (Hoving, 2007: 149). Pemimpin harus bisa beradaptasi dengan perkembangan zaman. Selain itu pemimpin harus memiliki empati dan wawasan yang tinggi dan komitmen dalam menolong sesama tanpa membedakan suatu agama, suku, maupun ras masyaraktnya (Irawan, 2019: 8).

\section{Konsep Kepemimpinan \\ Definisi Kepemimpinan}

Menurut Stoner (1968: 276), Kepemimpinan adalah Sebuah proses dalam mengarahkan atau memengaruhi kegiatan terkait sebuah organisasi atau kelompok demi mencapai tujuan tertentu dan juga menurut Sondang P. Siagian (1965), Kepemimpinan dapat diartikan sebagai kemampuan seseorang saat menjabat sebagai pimpinan organisasi tertentu dalam memengaruhi orang lain, khususnya bawahannya. Ini dilakukan supaya mereka mampu bertindak dan berpikir sesuai dengan arahan 
tertentu supaya tujuan dapat tercapai dengan mudah. Menurut Hemhiel dan Coons (2017: 7), Kepemimpinan adalah perilaku individu ketika memimpin aktivitas dalam kelompok atau organisasi untuk mencapai tujuan bersama atau shared goal.

Menurut Wahjosumidjo (2002: 105), kepemimpinan memiliki beberapa implimikasi antara lain:

a. Kepemimpinan berarti melibatkan orang atau pihak lain, yaitu karyawan atau bawahan (followers). Para karyawan atau bawahan harus memiliki kemauan untuk menerima arahan dari pemimpin. Walaupun demikian, tanpa adanya karyawan, tidak ada pemimpin.

b. Seseorang pemimpin yang efektif adalah seseorang dengan kekuasanya mampu menggugah pengikutnya untuk mencapai kinerja yang memuaskan. Para pemimpin dapat menggunkan bentuk-bentuk kekuasaan atau kekuasaan yang berbeda untuk memengaruhi perilaku bawahan dalam berbagai situasi.

c. Kepemimpinan harus memiliki kejujuran terhadap diri sendiri, sikap bertagung jawab yang tulus, memiliki pengetahuan dan keberanian bertindak dengan keyakinan, serta kepercayaan pada diri sendiri dan orang lain untuk meyakinkan orang lain dalam membangun sebuah organisasi.

\section{Teori Kepemimpinan}

Teori kepemimpinan pada dasarnya merupakan kajian tentang individu yang memiliki karakteristik fisik, mental, dan kedudukan yang dipandang lebih daripada individu lain dalam suatu kelompok sehingga individu yang bersangkutan dapat mempengaruhi individu lain dalam kelompok tersebut untuk bertindak ke arah pencapaian suatu tujuan (Suhadi dkk, 2020: 134) dan (Mustomi dkk, 2020: 74,75).

Menurut Kartono (2006: 27), teori kepemimpinan adalah penggeneralisasian satu seri perilaku pemimpin dan konsep-konsep kepemimpinanya, dengan menonjolkan latar belakang historis, sebab-musabab timbulnya kepemimpinan, persyaratan menjadi pemimpin, sifat-sifat utama pemimpin, tugas pokok dan fungsinya, serta etika profesi kepemimpinan. Menurut Kartono (2006: 72), teori kepemimpinan terbagi atas tiga yaitu:

a. Teori sifat

Teori sifat yaitu teori yang berusaha untuk mengindentifikasikan karakteristik khas (fisik, mental, kepribadian) yang dikaitkan dengan keberhasilan kepemimpinan. Ada beberapa ciri-ciri unggul sebagai predisposisi yang diharapkan akan memiliki oleh seorang pemimpin, yaitu intelegensi tinggi, banyak inisiatif, energik, punya kedewasaan emosional, memiliki daya persuasif dan keterampilan komunikatif dan lain-lain.

b. Teori kepribadian

Dalam teori kepribadian menyatakan bahwa seorang pemimpin itu selalu berkelakuan kurang lebih sama, yaitu tidak melakuakan tindakan-tindakan yang identik sama dalam setiap situasi. Karena kepemimpinan jenis ini akan muncul berdasarkan kualitas pribadi dalam melakukan kepemimpinanya.

c. Teori kepemimpinan situasional

Suatu pendekatan terhadap kepemimpinan yang menyatakan bahwa pemimpin memahami perilakunya, sifat-sifat bawahanya, dan situasi sebelum menggunkan suatu gaya kepemimpinan tertentu.

Adapun contoh pengertian kepemimpinan sebagai perilaku dikemukakan oleh Sweeney dan Mc Farlin (2002) yakni: "Leadership involves a set of interpersonal influence processes. The processes are aimed at motivating sub-ordinates, creating a vision for the future, and developing strategies for achieving goals", yang dapat diartikan bahwa kepemimpinan melibatkan_seperangkat proses pengaruh antarorang. Proses tersebut bertujuan memotivasi bawahan, menciptakan visi masa depan, dan mengembangkan strategi untuk mencapai tujuan (Stoner, 1968: 276). 


\section{Gaya kepemimpinan}

Gaya kepemimpinan yang sebaiknya dijalankan oleh seorang pemimpin terhadap organisasinya sangat tergantung pada kondisi anggota organisasi itu sendiri. Pada dasarnya tidak semua gaya kepemimpinan akan memiliki kecocokan untuk semua kondisi (Hersey \& Blanchard, 1982). Dengan mengetahui kondisi nyata karyawan, seorang pemimpin dapat memilih gaya kepemimpinan yang paling tepat, dimana gaya kepemimpinan yang paling tepat yaitu gaya kepemimpinan yang dapat memaksimalkan kinerja anggotanya, dan mudah dalam menyesuaikan dengan segala situasi dalam organisasi (Rotemberg dkk, 1993: 1305).

Gaya kepemimpinan yang efektif sangat berorientasi pada bawahannya yang bergantung pada komunikasi untuk tetap menjaga agar semua orang bekerja sesuai dengan unit pekerjaannya masing-masing (Azzahra dkk, 2019: 5). Itulah ulasan mengenai gaya kepemimpinan, jenis-jenisnya dan gaya kepemimpinan yang seperti apa yang disebut gaya kepemimpinan ideal. Setiap karyawan akan menjalankan tugasnya dengan senang hati tanpa keterpaksaan jika pemimpin memiliki gaya kepemimpinan yang baik dan efektif. Sebaliknya, gaya kepemimpinan yang tidak efektif tidak akan memberikan pengarahan yang baik pada bawahannya sehingga sebagian besar karyawan melakukan pekerjaan dengan keterpaksaan dan memberikan hasil yang tidak maksimal. Oleh karena itu, dibutuhkan hubungan kerja yang baik antara pemimpin dengan karyawannya (Riyadi, 2019: 42).

Menurut Siagian (2005:83), gaya kepemimpinan dapat dikategorikan dalam lima tipe, yaitu:

1. Gaya otokratik yaitu di dalam pengambilan keputusan, seseorang manajer yang otkratik akan bertindak sendiri, mengunakan pendekatan formal dalam pemeliharaan hubungan. Gaya otokratik berpendapat bahwa para bawahnya mempunyai tingkat kedewasaan lebih rendah dari pada pemimpin.

2. Gaya paternalistik yaitu kepemimpinan yang menunjukan kecenderungan pengambilan keputusan sendiri dan berusaha menjualnya kepada bawahan, memerlukan bawahannya sebagai orang yang belum dewasa, dan berorientasi terhadap penyelesaian tugas dan hubungan baik dengan bawahan.

3. Gaya karismatik dalam pengambilan keputusan dapat bersifat otokratik dan demokratis. Gaya kepemimpinan kharismatik mengedepankan hubungan dengan bawahan yang orientasi relasional bukan kekuasaan dan berusaha agar tugastugas terselenggara dengan sebaik-baiknya.

4. Gaya laissez faire mempunyai karakteristik yang paling menonjol terlihat pada gayanya yang santai dalam memimpin organisasi. Dalam hal pemeliharaan hubungan dengan para bawahanya, gaya kepemimpinan ini pada umumnya sangat mementingkan orientasi yang sifatnya relasional.

5. Gaya demokratif dianggap paling ideal. Karakteristik dari gaya kepemimpian demokratif terlihat dari hal hubungan yang menekankan hubungan serasi dengan bawahan, memperlakukan bawahan sebagai orang yang dewasa, dan menjaga keseimbangan orientasi penyelesaian tugas-tugas dan orientasi hubungan yang sifatnya relasional.

\section{Teori perbedaan generasi}

Perbedaan generasi dalam suatu lingkungan kerja menjadi salah satu subyek yang selalu muncul dalam perkembangan manajemen sumberdaya manusia dan konsep perbedaan generasi terus berkembang dari waktu ke waktu. Mengadopsi teori generasi yang dicetuskan oleh William Strauss dan Neil Howe dalam kajiannya mengenai identifikasi siklus generasi di Amerika Serikat. Strauss dan Howe (1991), menuliskan teori mengenai generasi ini dalam buku yang berjudul Generations: The History ofAmerica's Future, 1584 to 2069 (1991), yang menceritakan mengenai sejarah 
suksesi generasi anglo-American serta mengidentifikasi munculnya siklus generasi di sejarah Amerika Serikat. Staruss dan Howe mempublikasikan buku keduanya pada tahun 1993 yang berjudul 13th Gen: Abort, Retry, Ignore, Fail, yang menjelaskan generasi kelahiran 1961-1981 sebagai Gen-Xers disebut generasi ke-13 terhitung sejak Amerika Serikat resmi menjadi sebuah negara. Lalu pada 2000 Strauss dan Howe juga mengeluarkan sebuah buku dengan judul Millenials Rising: The Next Generation yang meneliti mengenai kepribadian mengenai Gen Y. Sejak munculnya Teori Generasi (Generation Theory), kita diperkenalkan istilah traditionalist,baby boomers, generasi $\mathrm{X}, \mathrm{Y}, \mathrm{Z}$ dan alpha. Segala sesuatu terutama yang berhubungan dengan prilaku, gaya hidup, profesi, budaya yang sering dikaitkan dengan ciri-ciri dari generasi-generasi tersebut. Teori yang dikemukakan oleh Strauss dan Howe merupakan asumsi yang sangat subjektif. Dalam tulisan ini penulis akan mengadopsi teori Generasi dalam memahami khalayak politik di Indonesia. Dengan perspektif yang disesuaikan dengan sejarah dan budaya Indonesia,penulis membuat rentan waktu setiap generasi disesuaikan dengan kejadian-kejadian yang sangat berpengaruh kepada suatu generasi sesuai eranya (Azzahra dkk, 2019: 5).

Menurut Bencsik \& Machova (2016: 82), ada 5 generasi yang lahir setelah perang dunia kedua dan berhubungan dengan masa kini menurut teori generasi, yaitu:

1. Baby Boomer (1946 - 1964)

Generasi yang lahir setelah Perang Dunia II ini memiliki banyak saudara, akibat dari banyaknya pasangan yang berani untuk mempunyai banyak keturunan. Generasi yang adaptif, mudah menerima dan menyesuaikan diri. Dianggap sebagai orang lama yang mempunyai pengalaman hidup.

2. Generasi X (1965-1980)

Tahun-tahun ketika generasi ini lahir merupakan awal dari penggunaan PC (personal computer), video games, tv kabel, dan internet. Penyimpanan datanya pun menggunakan floopy disk atau disket. MTV dan video games sangat digemari masa ini. Menurut hasil penelitian yang dilakukan oleh Jane Deverson, sebagian dari generasi ini memiliki tingkah laku negatif seperti tidak hormat pada orang tua, mulai mengenal musik punk, dan mencoba menggunakan ganja.

3. Generasi Y (1981-1994)

Dikenal dengan sebutan generasi millenial atau milenium. Ungkapan generasi $Y$ mulai dipakai pada editorial koran besar Amerika Serikat pada Agustus 1993. Generasi ini banyak menggunakan teknologi komunikasi instan seperti email, SMS, instan messaging dan media sosial seperti facebook dan twitter. Mereka juga suka main game online.

4. Generasi Z (1995-2010)

Disebut juga Generation, generasi net atau generasi internet. Mereka memiliki kesamaan dengan generasi $\mathrm{Y}$, tapi mereka mampu mengaplikasikan semua kegiatan dalam satu waktu seperti ngetweet menggunakan ponsel, browsing dengan PC, dan mendengarkan musik menggunakan headset. apa pun yang dilakukan kebanyakan berhubungan dengan dunia maya. Sejak kecil mereka sudah mengenal teknologi dan akrab dengan gadget canggih yang secara tidak langsung berpengaruh terhadap kepribadian mereka.

5. Generasi Alpha (2011-2025).

Generasi yang lahir sesudah generasi $Z$, lahir dari generasi $X$ akhir dan $Y$. Generasi yang sangat terdidik karena masuk sekolah lebih awal dan banyak belajar, rata-rata memiliki orang tua yang kaya.

\section{METODOLOGI}

Pada penelitian ini mengunakan jenis atau pendekatan penelitian yang berupa studi kepustakaan (Library Research). Studi kepustakaan merupakan suatu studi yang digunakan dalam mengumpulkan informasi dan data dengan bantuan berbagai macam 
materi yang ada di perpustakaan seperti dokumen-dokumen, baik dokumen tertulis, gambar maupun elektronik maupun buku-buku yang membahas tentang kepemimpinan, jurnal dan penelitian yang telah dilakukan yang berkaitan dengan kepemimpinan ideal pada era generasi milenial (Mardalis, 1999: 142).

Studi kepustakaan juga dapat mempelajari berbagai buku refrensi serta hasil penelitian sebelumnya yang sejenis yang berguna untuk mendapatkan landasan teori mengenai masalah yang akan diteliti (Sarwono, 2006: 123). Studi kepustakaan juga berarti teknik pengumpulan data dengan melakukan penelaahan terhadap buku literatur, catatan, serta berbagai laporan yang berkaitan dengan masalah yang ingin dipecahakan (Nazir, 1988: 58). Sedangkan menurut ahli lain studi kepustakaan merupakan kajian teoritis, refrensi serta literatur ilmiah lainya yang berkaitan dengan budaya, nilai dan norma yang berkembang pada situasi sosial yang di teliti (Sugiyono, 2012: 46).

\section{HASIL DAN PEMBAHASAN \\ Hakikat Gaya Kepemimpinan Yang Ideal Pada Generasi Milenial}

Gaya kepemimpinan yang sebaiknya dijalankan oleh seorang pemimpin terhadap organisasinya sangat tergantung pada kondisi anggota organisasi itu sendiri. Pada dasarnya tidak semua gaya kepemimpinan akan memiliki kecocokan untuk semua kondisi (Azzahra dkk, 2019: 5). Dengan mengetahui kondisi nyata karyawan, seorang pemimpin dapat memilih gaya kepemimpinan yang paling tepat, dimana gaya kepemimpinan yang paling tepat yaitu gaya kepemimpinan yang dapat memaksimalkan kinerja anggotanya, dan mudah dalam menyesuaikan dengan segala situasi dalam organisasi (Rotemberg dkk, 1993: 1312).

Kepemimpinan milenial diterjemahkan sebagai kepemimpinan masa kini yang menyesuaikan dengan gaya generasi baru yang lahir pada era 1980-an. Pola kepemimpinan milenial tidak sama dengan pola kepemimpinan lama dari generasi sebelumnya. Tahun kelahiran 1980-an memegang peran penting karena generasi tersebut saat ini memasuki masa paling produktif . Di usia 30- an tahun, generasi inilah yang menggerakkan dunia kerja, dunia kreativitas, dunia inovasi, dan memengaruhi pasar dan industri global yang ada sekarang dan sedang menggelinding di lapangan kompetisi dunia kerja, dunia kreativitas, dan dunia inovasi. Karena itu pula, generasi yang lahir pada era 1980-an ke atas biasa disebut generasi milenial (Hambali, 2019: 114).

Dengan merujuk pada generasi itu, gaya kepemimpinan yang dibangun pun perlu beradaptasi dengan pola pikir dan gaya hidup mereka. Dan ketika kepemimpinan yang ada hendak melakukan revolusi mental pada bangsa, generasi inilah yang menjadi target penting untuk disasar.

Beberapa karakter generasi milenial ini adalah; (1). Kemampuan mereka mengakses teknologi informasi yang lebih baik dari generasi sebelumnya. Media sosial menjadi bagian kehidupan mereka sehari-hari. Internet pun menjadi sumber informasi dan pengetahuan bagi mereka. Apa pun kebutuhan informasi yang mereka perlukan, sebagian besar mereka peroleh dari internet dan media sosial; (2). Generasi milenial lebih memiliki keberanian dalam berinovasi. Mereka lebih termotivasi menciptakan startup atau merintis usaha dan bisnis baru. Karena itu merupakan bagian dari tantangan yang membuat adrenalin mereka mengalir; (3). generasi milenial lebih menyukai independensi dan kemandirian. Independensi ini merupakan kebutuhan yang lahir dari gaya hidup yang ingin lebih bebas dan mandiri dalam melakukan sesuatu; (4). generasi milenial lebih menyukai sesuatu yang instan. Mungkin ciri ini bisa dipersepsikan secara positif atau negatif. Positifnya, generasi ini menyukai sesuatu yang praktis dan simpel. Negatifnya, generasi ini mungkin memiliki daya tahan yang lebih rendah terhadap tekanan dan stres karena terbiasa melakukan sesuatu dengan cepat dan instan sehingga kurang sabar jika hasil yang diperoleh tidak muncul seketika (Permatasari dkk, 2018: 76). Dengan memahami karakter generasi milenial 
ini, kepemimpinan yang muncul pun perlu menjadi bagian dari figur yang cocok dengan mereka. Penerjemahan tentang kepemimpinan milenial ini pun fleksibel dan belum ada definisi mutlak dari para pakar kepemimpinan (Mustomi dkk, 2020: 74).

Meski demikian, beberapa yang dapat ditekankan dalam pola kepemimpinan ini antara lain; (1). Kepemimpinan milenial perlu memahami dan memakai pola komunikasi generasi milenial yang dipimpinnya. Misalnya pemimpin milenial tidak segan menggunakan media sosial seperti Twitter, Facebook, Instagram, You-Tube, Me-Tube, dan saluran komunikasi terbaru yang memang menjadi arus utama dalam kehidupan generasi baru itu; (2). Kepemimpinan milenial perlu mendorong inovasi, kreativitas, dan jiwa entrepreneurship generasi baru itu. Semua saluran inovasi, kreativitas dan entrepreneurship harus dirancang dengan baik dan kongkrit. Tidak hanya berisi wacana saja, tetapi juga terdapat proses yang benarbenar dapat dinikmati oleh generasi milenial untuk mengembangkan dirinya. Misalnya pemimpin milenial perlu membangun pusatpusat kreativitas di setiap kota, membangun sebanyak mungkin workshop dengan peralatan dan teknologi terbaru dengan maksud agar gagasan dan ide generasi milenial itu tersalurkan; (3). Kepemimpinan milenial perlu mendukung kemandirian dan jiwa entrepreneurship generasi milenial. Membangun bangsa harus memiliki fondasi utama yakni kemandirian dan entrepreneurship (Permatasari dkk, 2018: 75-76).

\section{Tantangan Gaya Kepemimpinan Ideal pada Generasi Milenial}

Pada era generasi milenial saat ini pergolakan dan tantangan untuk memiliki pemimpin yang sesuai dengan era saat ini sangatlah besar. Tak terkecuali di Indonesia. Walaupun banyak survei yang menyebutkan bangsa Indonesia sudah ada pada jalur yang benar namun survei-survei tersebut belum menyentuh pada lapisanlapisan pemimpin pada pemerintahan daerah. Di mana banyak pemimpin-pemimpin yang muncul akibat politik praktis. Seorang pemimpin dalam pemerintahan merupakan abdi rakyat walaupun dalam konotasi pemerintah diartikan sebagai perintah penguasa yang rata-rata dialami oleh bangsa yang terjajah. Berbeda dengan istilah government yang berindikasi mengelola kesejahteraan umum. Indikasi ini mengingatkan orang yang sedang berkuasa agar mengayomi rakyat. Dia sekaligus merupakan abdi rakyat dan abdi negara (Wahyudi dkk, 2018: 12).

Pada akhirnya pemerintahan yang efektif akan terwujud apabila para pemimpin di republik ini memenuhi kualifikasi-kualifikasi sebagai pemimpin yang kredibel, mempunyai kemampuan, intelektual, dan visi yang jauh kedepan. Namun pemimpin yang baik juga harus memiliki integritas, kejujuran, kesetiaan pada kepentingan rakyat. Seorang pemimpin harus selesai terhadap dirinya sendiri. Dia tidak boleh mementingkan kepentingan pribadi, kelompok, maupun partai di atas kepentingan rakyat yang dipimpinnya. Sistem perpolitikan di negara kita juga harus diperbaiki.

Banyak juga orang yang memiliki kualitas sebagai pemimpin namun enggan untuk maju. Dorongan untuk mencapai pemerintahan yang efektif dalam kepemimpinan yang bijaksana diharapkan akan membuat sistem yang baik untuk mencapai Indonesia menjadi bangsa yang maju dari segala macam bidang, menjadi negara yang berdaulat, terciptanya keadilan sehingga akhir yang bahagia adalah kesejahteraan rakyat yang mandiri akan tercapai (Mustomi dkk, 2020: 74). Mewujudkan Gaya Kepemimpinan yang Ideal pada Generasi Milenial Praktek kepemimpinan berkembang mengikuti perkembangan zaman. Kepemimpinan pada masa milenial memiliki pendekatan yang khas karena digitalisasi yang merambah dunia kerja tidak lagi memungkinkan pemimpin untuk bertindak secara konvensional. Di samping itu, dibutuhkan karakter kepemimpinan yang mampu mereduksi berbagai sikap negatif dan mampu mengeluarkan semua potensi positif dari kaum milenial seperti melek teknologi, cepat, haus ilmu pengetahuan, dan publikasi (Haryati. 2021: 77). 
Di bawah ini terdapat 6 (enam) karakter kepemimpinan yang dibutuhkan pada masa generasi milenial sebagai berikut:

\section{Digital Mindset}

Dengan semakin banyaknya orang yang menggunakan smartphone, maka akses komunikasi antar individu pun sudah tidak bersekat lagi. Ruang pertemuan fisik beralih ke ruang pertemuan digital. Pemimpin pada era milenial harus bisa memanfaatkan kemajuan teknologi ini untuk menghadirkan proses kerja yang efisien dan efektif di lingkungan kerjanya. Misalnya dengan mengadakan rapat via WA ataupun Anywhere Pad, mengganti surat undangan tertulis dengan undangan via email ataupun Telegram, dan membagi product knowledge via WA. Jika seorang pemimpin tidak berupaya mendigitalisasi pekerjaannya pada era saat ini, maka dia akan dianggap tidak adaptif. Seperti yang dilansir oleh DDI (Development Dimensions International) dalam penelitiannya di tahun 2016, mayoritas millenial leader menyukai sebuah perusahaan yang fleksibel terhadap jam kerja dan tempat mereka bekerja. Hal ini tentu saja disebabkan karena kecanggihan teknologi yang membuat orang bisa bekerja dimana saja dan kapan saja. Dapat disaksikan bahwa hari ini banyak sekali coffeeshop yang berfungsi sebagai co-working space bertebaran di tempat kita dan sebagian besar pengunjungnya adalah millenial (Afifin, 2021: 11).

\section{Observer dan Active Listener}

Pemimpin pada masa milenial harus bisa menjadi observer dan pendengar aktif yang baik bagi anggota timnya. Apalagi jika mayoritas timnya adalah kaum milenial. Hal ini dikarenakan kaum milenial tumbuh beriringan dengan hadirnya media sosial yang membuat mereka kecanduan untuk diperhatikan. Mereka akan sangat menghargai dan termotivasi jika diberikan kesempatan untuk berbicara, berekspresi, dan diakomodasi ide-idenya. Mereka haus akan ilmu pengetahuan, pengembangan diri dan menyukai untuk berbagi pengalaman.

\section{Agile}

Pemimpin yang agile dapat digambarkan sebagai pemimpin yang cerdas melihat peluang, cepat dalam beradaptasi, dan lincah dalam memfasilitasi perubahan. Agile adalah pemimpin yang open minded dan memiliki ambiguity acceptance, yakni bersedia menerima ketidakjelasan. Pemimpin yang agile mampu mengajak organisasinya untuk dengan cepat mengakomodasi perubahan.

\section{Inclusive}

Di dalam bahasa Inggris, inclusive diartikan "termasuk di dalamnya". Secara istilah, inclusive diartikan sebagai memasuki cara berpikir orang lain dalam melihat suatu masalah. Pemimpin yang inclusive dibutuhkan pada masa atau era milenial dikarenakan perbedaan cara pandang antar individu yang semakin kompleks. Hal ini diakibatkan oleh banyaknya informasi yang semakin mudah diakses oleh siapapun, dimanapun, dan kapanpun sehingga membentuk pola pikir yang berbeda antar individunya. Pemimpin yang inclusive diharapkan dapat menghargai setiap pemikiran yang ada dan menggunakannya untuk mencapai tujuan organisasi. Pemimpin juga harus memberikan pemahaman akan pentingnya nilai, budaya, dan visi organisasi kepada anggota timnya secara paripurna (Mustomi dkk, 2020: 75).

\section{Brave to be Different}

Pada zaman sekarang, masih banyak orang yang tidak berani untuk mengambil sebuah langkah atau keputusan penting dalam pencapaian cita-citanya karena hal tersebut bertentangan dengan kebiasaan orangorang di sekitarnya. Hal semacam ini jika dibiarkan, akan menjadi hambatan seseorang bahkan sebuah organisasi untuk lebih maju. Ini adalah tantangan bagi para pemimpin milenial dalam mengubah kondisi 
tersebut dan menanamkan nilai bahwa perbedaan itu boleh asalkan dengan perencanaan dan tujuan yang jelas pastinya.

\section{Unbeatable (Pantang Menyerah)}

Mindset pantang menyerah tentu harus dimiliki oleh semua pemimpin. Apalagi memimpin anak-anak pada generasi milenial yang lekat dengan sikap malas, manja, dan merasa paling benar sendiri. Pemimpin milenial wajib memiliki sikap positive thinking dan semangat tinggi dalam mengejar goals-nya. Hambatan yang muncul seperti kurangnya respect dari pegawai senior maupun junior harus bisa diatasi dengan sikap ulet dan menunjukkan kualitas diri. Kondisi persaingan kerja pada era globalisasi harus memicu pemimpin untuk meningkatkan soft skills misalnya kemampuan bernegosiasi, menginspirasi, dan critical thinking, dan hardskills-nya. Maka dari itu, wajib bagi pemimpin untuk menjadi sosok yang unbeatable yang memiliki kemampuan bangkit dari kegagalan dengan cepat dan pantang menyerah dalam menggapai tujuan utamanya (Haryati. 2021: 77).

\section{SIMPULAN}

Kesimpulan yang diperoleh Kepemimpinan dapat diartikan sebagai kemampuan seseorang saat menjabat sebagai pimpinan organisasi tertentu dalam memengaruhi orang lain, khususnya bawahannya. Ini dilakukan supaya mereka mampu bertindak dan berpikir sesuai dengan arahan tertentu supaya tujuan dapat tercapai dengan mudah. gaya kepemimpinan yang ideal pada generasi milineal yaitu pemerintahan yang efektif akan terwujud apabila para pemimpin dapat memenuhi kualifikasi sebagai pemimpin yang kredibel, mempunyai kemampuan, intelektual, visi yang baik dan memiliki integritas, kejujuran dan kesetiaan pada kepentingan dalam masyarakat. Membangun suatu daerah yang dipimpin harus memiliki fondasi yakni kemandirian dan entrepreneurship yang memberikan kesenangan dan kepuasan kepada masyarakatnya. Kepemimpinan pada era milineal memiliki pendekatan yang khas karena digitalisasi yang merambah dunia kerja tidak lagi memungkinkan pemimpin untuk bertindak secara konvensional.

\section{DAFTAR PUSTAKA}

Arifin, Antoni Ludfi. (2021). "Karakter Kepemimpinan Cendekia pada Generasi Milenial." Fokus Bisnis: Media Pengkajian Manajemen Dan Akuntansi, 20 (1), 115.

Azzahra, C., \& Nurani, F. (2019). Pemimpin Agile pada Era Generasi Milenial (Studi pada Kepemimpinan Ridwan Kamil). Jurnal Kepemimpinan.

Dini Haryati, S. E., \& Ak, M. (2021). Tantangan Kepemimpinan Bagi Generasi Milenial Di Era Digital. Leadership di Era Digital, 77.

Hambali, I. M. (2019). Revitalisasi Konseling Keluarga: Meningkatkan Peran Keluarga dalam Memandirikan Anak. Konvensi Nasional Bimbingan dan Hoving, R. (2007). Information technology leadership challenges-past, present, and future. Information Systems Management, 24 (2), 147-153. Konseling XXI, 198-205.

Hersey, P., \& Blanchard, K. H. (1982). Leadership style: Attitudes and behaviors 
Hoyt, G. C., \& Stoner, J. A. (1968). Leadership and group decisions involving risk. Journal of Experimental Social Psychology, 4 (3), 275-284.

Irawan, I. K. A. (2019). Persona Pemimpin Muda Di Era Revolusi Industri 4.0. In Prosiding Seminar Nasional Institut Agama Hindu Negeri Tampung Penyang Palangka Raya, No. 1, 1-10.

Jonathan, Sarwono. (2006). Metode Penelitian Kuantitatif dan Kualitatif. Yogyakarta: Graha IImu.

Morris, E. (2021). Aceh: Social revolution and the Islamic vision. In Regional dynamics of the Indonesian revolution. University of Hawaii Press.

Mustomi, D., \& Reptiningsih, E. (2020). Gaya Kepemimpinan Dalam Perspektif Generasi Millenial. Jurnal IImiah MEA (Manajemen, Ekonomi, \& Akuntansi), 4(1), 189-199.

Nazir. (1988). Metodologi penelitian. Jakarta: Ghalia Indonesia.

Novitria, F. (2020). Studi Literatur Mengenai Karakteristik Kepemimpinan Dalam Lingkup Industri Dan Organisasi Di Era Generasi Milenial. In Prosiding Seminar Nasional LP3M, Vol. 2.

Rais, N. S. R., DIEN, M. M. J., \& DIEN, A. Y. (2018). Kemajuan teknologi informasi berdampak pada generalisasi unsur sosial budaya bagi generasi milenial. Jurnal Mozaik, 10 (2), 61-71.

Riyadi, S. (2011). Pengaruh kompensasi finansial, gaya kepemimpinan, dan motivasi kerja terhadap kinerja karyawan pada perusahaan manufaktur di Jawa Timur. Jurnal manajemen dan kewirausahaan, 13 (1), 40-45.

Rotemberg, J. J., \& Saloner, G. (1993). Leadership style and incentives. Management Science, 39 (11), 1299-1318.

Saputro, R. A. (2021). The Utilization of Colonial Historical Sites in the City of Palembang as a Learning Resource Based on Outdoor Learning. Britain International of Linguistics Arts and Education (BIoLAE) Journal, 3 (2), 121-127.

Saputro, R. A., Idris, M., \& Suryani, I. (2020). Sejarah Dan Budaya Palembang Barat Sebagai Sumber Buku Saku Sejarah. Kalpataru: Jurnal Sejarah Dan Pembelajaran Sejarah, 6(1), 6-17.

Siagian, S. P. (1965). The development and problems of indigenous bureaucratic leadership in Indonesia. Indiana University.

Sugiono. (2012). Memahami Penelitian Kualitatif. Bandung: ALFABETA

Suhadi, S., \& Arifianto, Y. A. (2020). Pemimpin Kristen Sebagai Agen Perubahan di Era Milenial. EDULEAD: Journal of Christian Education and Leadership, 1 (2), 129-147.

Wahyudi, H. S., \& Sukmasari, M. P. (2018). Teknologi dan kehidupan masyarakat. Jurnal Analisa Sosiologi, 3 (1). 